Jurnal Ilmiah Mahasiswa Fakultas Hukum (JIM FH)

E-ISSN 2798-8457

Volume IV Nomor 1 (Januari 2021)

Fakultas Hukum Universitas Malikussaleh

\title{
AKIBAT HUKUM PENOLAKAN PENGESAHAN PERKAWINAN TERHADAP PASANGAN NIKAH SIRI \\ (Studi Putusan Nomor: 0650/Pdt.P/2017/MS.Bir)

\author{
${ }^{1}$ Nailul Amal, ${ }^{2}$ Faisal, ${ }^{2}$ Nurarafah \\ ${ }^{1}$ Mahasiswa Fakultas Hukum Universitas Malikussaleh \\ ${ }^{2}$ Dosen Fakultas Hukum Universitas Malikussaleh
}

\begin{abstract}
Marriage is an important event in human life that will have physical and mental consequences because with marriage a household can be upheld and fostered in accordance with religious norms and the order of life of society. The formulation of the problem in this study is how the judge's consideration in rejecting marriage ratification of unmarried couples (Case Study Number 0650 / Pdt.P / 2017 / MS.Bir). What is the legal effect of refusing legalization of marriage on unmarried couples. And legal protectyon for children born from unmarried couples. This study uses a normative juridical research method. As for the results of this study, it can be seen that the Judge's Consideration in rejecting marriage ratification of unmarried couples (Case Study Number 0650 / Pdt.P / 2017 / MS.Bir), the judge considered that both the wife and husband who proposed the merriage certifycate were rejected because both of them already have their respective wives and husbands, not to mention that the marriage between the two is an illegal marriage in the State so that the judge refuses to marry the two of them. The legal consequence of refusal to legalize marriage for unregystered merriage partners results in children in unregistered marriages, namely: The stetus of the child born is considered an illegitimate child. Legal protectyon for children born from unregystered merriages related to their civilization will return to the mother of the child and also do not receive inheritance or responsibility from a father.
\end{abstract}

Key Word: Law, Denial of Marriage, and Marriage Siri 


\section{PENDAHULUAN}

Perkawinan ialah suatu fenomena yang sangat sakral dalam kehidupan manusia, dimana dapat menimbulkan suatu ikatan yang sah karena dengan adanya perkawinan rumah tangga dapat berdiri tegak dan dibina sesuai dengan norma agama dan adat. Perkawinan merupakan suatu perjanjian perikatan antara laki-laki dan perempuan, dalam hal perkawinan merupakan perjanjian yang sakral untuk membentuk keluarga yang kekal dan bahagia. ${ }^{1}$

Pengertian perkawinan dalam Pasal 1 Undang-Undang Nomor 1 Tahun 1974 Tentang Perkawinan ${ }^{2}$ dinyatakan bahwa perkawinan adalah ikatan lahir dan batin antara seorang laki-laki dengan seorang perempuan sebagai suami isteri dengan tujuan membentuk keluarga yang bahagia dan kekal berdasarkan ketuhanan yang Maha Esa. ${ }^{3}$ Lebih lanjut, dalam Pasal 2 ayat (1) Undang-Undang Perkawinan yang menyatakan bahwa perkawinan sah, apabila dilakukan menurut hukum masing-masing agama dan kepercayaannya.

Dalam kehidupan dimasyarakat adakala perkawinan tanpa adanya pencatatan yang dilakukan oleh Negara, atau yang dikenal dengan nikah siri. Nikah siri merupakan suatu pernikahan yang telah memenuhi syarat dan rukun nikah, dalam Agama Islam karena alasan tertentu tidak dicatatkan di Kantor Urusan Agama (KUA). Secara hukum Islam, pernikahan tersebut dianggap sah oleh sebagian kalangan karena telah memenuhi kriteria keabsahan pernikahan yaitu dengan adanya ijab, qabul, dua orang mempelai, wali dan dua orang saksi. Nikah siri ada juga dijadikan sebagai alternatif mengantisipasi pergulan bebas antara laki-laki dan perempuan non muhrim yang secara psikologis, moril materil belum mempunyai kesiapan untuk menikah secara formal.

Banyaknya kalangan yang menganggap bahwa nikah siri tersebut merupakat suatu perkawinan yang sah akan tetapi hal tersebut membuat masyarakat menilai bahwa pernikahan merupakan sesuatu yang mudah untuk dilaksanakan, akibatnya dalam kehidupan berumahtanggapun dijalani tanpa mempertimbangkan aspek hukum formal yang berlaku. Pada kenyataannya justru menimbulkan berbagai permasalahan dan konflik rumah tangga yang berimbas kepada persoalan hukum yang sangat merugikan kaum perempuan.

Pernikahan siri juga memungkinkan timbulnya kekerasan terhadap istri. Oleh sebab itu seorang suami bebas melakukan apasaja terhadap istrinya, dan bila terjadi kekerasan atau pelanggaran-pelanggaran yang merugikan istri, istri tidak bisa menuntut, sementara suami mempunyai kebebasan secara hukum. Bahkan bila suami kemudian menikah lagi secara resmi dengan perempuan lain, istri tidak bisa berbuat apa-apa. Pentingnya pencatatan pernikahan atau dengan bahasa lain, ketika pernikahan tidak dicatatkan maka akan menimbulkan akibat hukum bagi pelaku perkawinan tersebut dan juga keturunannya. Diantara akibat pernikahan yang tidak dicatatkan adalah substansi

${ }^{1}$ M.Yusuf, My, Dampak Perceraian Orang Tua Terhadap Anak, Jurnal Al-Bayan, Vol, No. 29, Januari, 2014, hlm. 1.

${ }^{2}$ Undang-Undang Nomor 1 Tahun 1974 Tentang Perkawinan Selanjutnya dituliskan undangundang perkawinan.

${ }^{3}$ Undang-undang perkawinan. 
perkawinan dianggap tidak sah dimata hukum negara, istri dapat ditalak kapan saja, status hukum anak tidak jelas, hak istri dan anak atas nafkah dan juga warisan tidak terjamin. ${ }^{4}$

Upaya perkawinan yang belum tercatat diajukan itsbat nikah kepengadilan Agama. Sesuai dengan Undang-Undang Nomor 50 Tahun 2009 bahwa Pengadilan Agama berwenang secara absolut untuk menangani perkara ini. Dalam undang-undang tersebut telah dijelaskan bahwa Peradilan Agama adalah peradilan bagi orang-orang yang beragama Islam, dan pegawai pencatat nikah adalah pegawai pada KUA Agama. ${ }^{5}$ Itsbat nikah dapat diartikan sebagai suatu langkah atau upaya dari pemerintah bagi setiap pasangan yang belum memiliki akte nikah. Namun dalam permohonan itsbat nikah ini tidak semua yang belum memiliki akte nikah bisa mendapatkan hak pengakuan dari pengadilan, terkecuali telah terpenuhinya syarat-syarat atau kriteria perkawinan yang bisa diitsbatkan. ${ }^{6}$

Itsbat nikah menurut Keputusan Mahkamah Agung Republik Indonesia Nomor KMA/032/SK/2006 tentang Pedoman Pelaksanaan Tugas dan Administrasi Pengadilan adalah pengesahan atas perkawinan yang telah dilangsungkan menurut syariat Agama Islam, akan tetapi tidak dicatat oleh Kantor Urusan Agama atau Pegawai Pencatat Nikah yang berwenang. Itsbat nikah juga mengandung arti suatu metode atau cara dalam menetapkan sahnya suatu perkawinan yang belum tercatat di Kantor Urusan Agama setempat, sesuai dengan ketentuan-ketentuan hukum yang berlaku terkait dengan hal perkawinan yang dilaksanakan di pengadilan. ${ }^{7}$

Penelitian yang dikaji dalam permasalahan putusan pada Mahkamah Syar'iyah Bireun Nomor 0650/Pdt.p/2017/MS.Bir dengan posisi kasus sebagai berikut. Para pihak telah menikah sah menurut syari'at Islam pada tanggal 01 Maret 2000 di Desa Kubu, Kecamatan Peusangan Siblah Krueng Kabupaten Bireuen dengan mahar berupa emas seberat 5 (lima) manyam. Pada saat pernikahan tersebut Pemohon I dan II berstatus jejaka dan berstatus perawan. Dan telah dikaruniai seorang anak, sampai sekarang para pihak belum memiliki kutipan akta nikah, karena pernikahannya tidak terdaftar di Kantor Urusan Agama Kecamatan Peusangan, dengan alasan kerusuhan konflik, sementara saat ini Pemohon I dan II membutuhkan Akta Nikah tersebut untuk pengurusan Kartu Keluarga, Kartu Tanda Penduduk, dan kepentingan hukum lainnya, maka dari itu pemohon meminta kepada Majelis Hakim untuk mencatat perkawinan tersebut. Setelah dipelajari lebih lanjut ditemukan bahwa pada saat menikah Pemohon I berstatus terikat perkawinan dengan perempuan lain dan Pemohon II terikat perkawinan dengan pria lain. ${ }^{8}$

\footnotetext{
${ }^{4}$ Endang Ali Ma'sum, Pernikahan yang Tidak Dicatatkan dan Problematiaknya, Jurnal Musawa, Vol. 12, No. 2, Juli 2013, hlm. 209-219.

${ }^{5}$ Kustini, Menelusuri Makna Dibalik Fenomena Perkawinan Dibawah Umur dan Perkawinan Tidak Tercatat, Kementerian Agama RI, Jakarta, hlm. 115.

${ }^{6}$ Pasal 7 ayat (3) Kompilasi Hukum Islam

${ }^{7}$ Keputusan Mahkamah Agung Republik Indonesia Nomor KMA/032/SK/2006 tentang Pedoman Pelaksanaan Tugas dan Administrasi Pengadilan.

${ }^{8}$ Putusan Nomor 0650/Pdt.P/2017/MS.Bir
} 
Mencermati jalan perkara kasus di atas, yang berkaitan dengan perkawinan dibawah tangan, menunjukkan betapa pentingnya sosialisasi hukum Islam kedalam masyarakat yang bukan saja bentuk rumusan hukum normatifnya. Berdasarkan latar belakang masalah yang telah diuraikan diatas maka penulis tertarik untuk melaksanakan penelitian dengan judul "Akibat Hukum Penolakan Pengesahan Perkawinan Terhadap Pasangan Nikah Siri (Studi Perkara Nomor 0650/Pdt.P/2017/MS.Bir)".

\section{METODE PENELITIAN}

Jenis penelitian yang digunakan dalam penelitian ini adalah jenis penelitian kualitatif, yaitu prosedur penelitian yang menghasilkan data deskriptif berupa kata-kata tertulis atau tulisan dari orang-orang dan perilaku yang diamati dan berupaya mencari makna. ${ }^{9}$ Metode pendekatan yang digunakan dalam penelitian ini adalah penelitian hukum normatif. Penelitian ini bersifat deskriptif, yaitu menggambarkan, menelaah, menjelaskan secara tepat dengan toeri-teori hukum dalam praktek pelaksanaan hukum positif sehubungan dengan masalah yang diteliti.

\section{PEMBAHASAN}

\section{Tinjauan Umum Tentang Perkawinan}

1. Pengertian Perkawinan

Perkawinan berasal dari kata "kawin" yang menurut bahasa berarti membentuk keluarga dengan lawan jenis, melakukan hubungan kelamin atau bersetubuh. Perkawinan berasal dari kata wathi yang menurut bahasa berarti mengumpulkan, saling memasukkan, dan bersetubuh. ${ }^{10}$ Istilah nikah berasal dari bahasa Arab yaitu annikah, ada pula yang mengatakan perkawinan menurut istilah fikih dipakai perkataan nikah dan perkataan zawaf. ${ }^{11}$ Nikah secara etimilogis digunakan untuk mengungkapkan arti persetubuhan, akad, dan pelukan. ${ }^{12}$

Berdasarkan”Pasal 1 Undang-Undang Nomor 1 Tahun 1974 Tentang Perkawina yaitu ikatan lahir dan batin antara seseorang pria dan seorang wanita sebagai suami istri dengan tujuan membentuk keluarga (rumah tangga) yang bahagia kekal berdasarkan Ketuhanan Yang Maha Esa. Pasal 2 Kompilasi Hukum Islam (KHI) memberikan pengertian perkawinan menurut hukum Islam adalah pernikahan, yaitu akad yang sangat kuat atau miitsaaqan ghaliizhan untuk menaati perintah Allah Swt. Dan melakukannya merupakan ibadah.

2. Sumber Hukum Perkawinan

\footnotetext{
${ }^{9}$ Lexy J. Moleong, Penelitian Kualitatif Remaja Rosdakarya, Remaja Rosdakarya, Bandung, 2007, hlm. 9.

${ }^{10}$ Abdul Rahman Ghozali, Fiqh Munakat, Pernada Media Group, Jakarta, 2003, hlm. 8.

${ }^{11}$ Kamal Mukhtar, Asas-Asas Hukum Islam Tentang Perkawinan, Bulan Bintang, Jakarta, 1974, hlm. 79.

${ }^{12}$ Abdul majid Mahmud Mathalub, Panduan Hukum Keluarga Sakinah, Intermedia, Solo, 2005, hlm. 1 .
} 
Dasar hukum perkawinan bersumber dari al-Quran dan Hadis yang kemudian dituangkan dalam garis-garis hukum melalui Undang-undang Nomor 1 Tahun 1974 Tentang Perkawinan dan Kompilasi Hukum Islam (KHI). Pasal 2 ayat (1) dan ayat (2) menyatakan bahwa: Ayat (1) perkawinan sah, apabila dilakukan menurut hukum masing-masing agamanya dan kepercayaannya itu. Ayat (2) tiap-tiap perkawinan dicatat menurut peraturan perundang-undangan yang berlaku. ${ }^{13}$

Perkawinan adalah untuk mewujudkan kedamaian dan ketentraman hidup serta menumbuhkan rasa kasih sayang khususnya antara suami-istri, kalangan keluarga yang lebih luas, bahkan dalam kehidupan umat manusia umumnya. Ketentuan ini terdapat dibeberapa ayat al-Quran dalam surat Al-Rum ayat 21 yang artinya: "diantara keagungan dan kekuasaan Allah ialah diciptakannya istri-istri bagi kaum laki-laki dari jenis manusia yang sama, guna menyelenggarakan kehidupan damai dan tentram, serta menimbulkan rasa kasih sayang antara suami istri khususnya dan umat manusia umumnya",14. (QS. Al-Rum:21)

Berdasarkan ayat-ayat diatas selain dalam al-Quran, perkawinan juga disebutkan dalam hadis dan Ijmak Ulama Fikih, diantaranya yaitu: Hadis yang diriwayatkan oleh Abi Ayyub. Ra., bahwa Rasulullah Saw bersabda: "empat hal yang merupakan sunnah Rasul yaitu Hinna, Berparfum, Siwak dan Menikah”. (HR At Tarmizi 1080).

3. Rukun Perkawinan

Undang-Undang Nomor 1 Tahun 1974 tidak mengenal adanya rukun nikah, namun hanya mengatur tentang syarat-syarat perkawinan. Sedangkan dalam KHI Pasal 14-17 menerangkan tentang rukun nikah dan syarat perkawinan. Rukun yang paling utama adalah calon suami istri yang telah cukup umur, hal ini sesuai dengan Pasal 15 ayat (1) bahwa untuk kemaslahatan keluarga dan rumah tangga perkawinan hanya boleh dilakukan oleh calon mempelai yang telah mencapai umur yang telah ditetapkan dalam Pasal 7, yakni calon suami sekurang-kurangnya berumur 19 tahun dan calon istri berumur 16 tahun. Ketentuan batas umur sejalan dengan prinsip yang diletakkan Undang-undang bahwa calon suami istri harus telah masak jiwa raganya, agar dapat mewujudkan tujuan perkawinan secara baik tanpa berfikir pada perceraian dan mendapat keturunan yang baik dan sehat. ${ }^{15}$

4. Syarat-Syarat Perkawinan

Syarat-syarat sah perkawinan sebagaimana telah diatur dalam undang-undang diantaranya: Persetujuan calon mempelai, Batas.umur.perkawinan, dan Perjanjian perkawinan.

5. Pencegahan Perkawinan

Pencegahan perkawinan dapat dimaknai dengan usaha untuk menyebabkan tidak berlangsungnya suatu perkawinan. Pencegahan perkawinan dilakukan sebelum terjadinya suatu perkawinan. Pasal 13 menyebutkan bahwa, perkawinan dapat

\footnotetext{
${ }^{13}$ Abdul Khadir M. Hukum Perdata Indonesia, Citra Aditya Bakti, Bandung, 2000, hlm. 74.

${ }^{14}$ QS. Al Rum Ayar 21

${ }^{15}$ Kompilasi Hukum Islam Pasal 14 dan 17 Ayat (1)
} 
dicegah apabila ada pihak yang tidak memenuhi syarat-syarat untuk melangsungkan perkawinan. $^{16}$

Pencegahan perkawinan biasanya berkenaan dengan masalah kafaah dan mahar. Kafaah dan mahar merupakan harga diri dan gengsi dalam suatu keluarga. Pihak keluarga perempuan mereka merasa harga dirinya jatuh bila anak perempuannya kawin dengan laki-laki yang tidak sekutu atau status sosialnya rendah. Tujuan dari pencegahan perkawinan ini adalah untuk menghindari suatu perkawinan yang dilarang hukum Islam dan peraturan Perundang-undangan. Oleh sebab itu maka suatu perkawinan haruslah memenuhi segala sesuatu yang memangharus dipenuhi untuk melakukan suatu perkawinan. ${ }^{17}$

\section{Perjanjian dalam Perkawinan}

Perjanjian perkawinan dibuat oleh calon suami dengan calon istri jika diperlukan untuk mengatur hal-hal yang berkaitan dengan harta kekayaan atau lainlainya. Perjanjian itu harus dibuat sebelum akat nikah dilangsungkan atau pada saat melakukan akad nikah. Hukum perkawinan bersifat fakultatif lebih banyak mengatur, maka dalam beberapa hal boleh disimpangi dengan membuat perjanjian perkawinan. ${ }^{18}$

\section{Pencatatan Perkawinan}

Pencatatan perkawinan adalah pencatatan atas perkawinan yang sah menurut hukum Islam atau perkawinan yang memenuhi rukun dan syarat perkawinan sesuai syariat Islam yang dilakukan di Kantor Urusan Agama. Pencatatan perkawinan bertujuan mewujudkan ketertiban perkawinan dalam masyarakat untuk melindungi martabat dan kesucian perkawinan dan khususnya bagi perempuan dalam kehidupan rumah tangga. ${ }^{19}$

Fungsi pencatatan perkawinan terdapat dalam penjelasan umum Undang-undang Perkawinan yaitu setiap pencatatan perkawinan adalah sama halnya dengan pencatatan peristiwa-peristiwa penting dalam kehidupan seseorang, misalnya kelahiran, kematian yang dinyatakan dalam surat-surat keterangan, suatu akta yang juga dimuat dalam daftar pencatatan.

8. Pembatalan dan Pengesahan Perkawinan (Itsbat Nikah)

Menurut bahasa itsbat nikah terdiri dari dua kata yaitu kata itsbat yang merupakan masdar atau asal kata dari atsbata yang memiliki arti menetapkan, dan kata nikah yang berasal dari kata nakaha yang memiliki arti saling menikah, dengan kata itsbat nikah memiliki arti yaitu penetapan pernikahan. Itsbat nikah sebenarnya sudah

${ }^{16}$ Jamaluddin dan Nanda Amalia, Op.Cit, hlm. 24.

${ }^{17}$ Ibid, hlm. 57.

${ }^{18}$ Ibid, hlm. 55.

${ }^{19}$ Itsnatul Lathifah, Pencatatan Perkawinan: Melacak Akar Budaya Hukum dan Respon Masyarakat Indonesia terhadap Pencatatan Perkawinan, Jurnal Al Mazahib, Vol. 3 No. 3 Juni 2015, hlm. 54. 
menjadi istilah dalam bahasa Indonesia dengan sebutan itsbat nikah. Menurut kamus bahasa Indonesia, itsbat nikah adalah penetapan tentang kebenaran (keabsahan) nikah. ${ }^{20}$

Itsbat nikah atau yang lebih dikenal dengan pengesahan perkawinan merupakan perkara voluntair dalam kewenangan Pengadilan Agama/ Mahkamah Syar'iyah. Perkara voluntair adalah jenis perkara yang hanya ada pihak pemohon saja, tidak ada pihak lawan dan tidak ada sengketa. ${ }^{21}$ Pasal 5 ayat (1) Undang-Undang Nomor 4 Tahun 2004 tentang Kekuasaan Kehakiman menentukan bahwa suatu pengadilan berwenang menyelesaikan perkara yang tidak mengandung sengketa apabila ada ketentuan atau penunjukkan dari undang-undang. Melakukan perceraian di luar pengadilan pun memang bukanlah sebuah kejahatan. Sebab hingga saat ini tidak ada satu aturanpun yang menyatakan bahwa perbuatan tersebut dapat dihukum. ${ }^{22}$ Dalam kompetensi absolut Pengadilan Agama/Mahkamah Syar'iyah, Undang-undang telah menunjuk beberapa kewenangan yang menyangkut perkara tanpa sengketa (voluntair), perkara yang dimaksud adalah: ${ }^{23}$ permohonan itsbat nikah, permohonan izin nikah, permohonan dispensasi kawin, permohonan penetapan wali adhal, dan permohonan penetapan ahli waris.

\section{Tinjauan Umum Pertimbangan Hakim dan Putusan Hakim}

\section{Pengertian Pertimbangan Hakim}

Pertimbangan Hakim merupakan salah satu aspek terpenting dalam menentukan terwujudnya nilai dari suatu putusan hakim yang mengandung keadilan dan mengandung kepastian hukum, disamping itu juga mengandung manfaat bagi para pihak yang bersangkutan sehingga pertimbangan hakim itu harus disikapi dengan teliti, baik dan cermat. Apabila pertimbangan hakim tidak teliti, baik dengan cermat, maka putusan hakim yang berasal dari pertimbangan hakim tersebut akan dibatalkan oleh Pengadilan Tinggi/Mahkamah Agung. ${ }^{24}$

2. Pengertian Putusan Hakim

Putusan hakim atau lazimnya disebut dengan putusan pengadilan. Putusan pengadilan merupakan sesuatu yang sangat dinantikan oleh pihak-pihak yang berperkara guna untuk menyelesaikan sengketa diantara mereka dengan sebaik-baiknya. Para pihak mengharapkan adanya kepastian hukum dan keadilan dalam putusan yang diputuskan oleh hakim, agar dapat memberikan putusan yang benar-benar menciptakan kepastian hukum dan mencerminkan keadilan, hakim sebagai aparatur negara yang

\footnotetext{
${ }^{20}$ Andi Nadir Mudar, Fenomena Itsbat Nikah Terhadap Perkawinan Yang Dilakukan Setelah Terbitnya Undang-Undang Nomor 1 Tahun 1974 Tentang Perkawinan, Jurnal Pemikiran Islam, Vol. 4, No. 2, Desember, 2018, hlm. 121.

${ }^{21}$ Jamaluddin dan Nanda Amalia, Op. Cit, hlm. 40.

${ }^{22}$ Fitri, Y., Jamaluddin, J., \& Faisal, F. (2019). Analisis Yuridis Perceraian di Luar Pengadilan Menurut Undang-undang Nomor 1 Tahun 1974 Tentang Perkawinan Dan Menurut Pendapat Ahli Fikih Islam. Suloh: Jurnal Fakultas Hukum Universitas Malikussaleh, 7(1), hlm. 49.

${ }^{23}$ M.Anshary MK, Hukum Perkawinan di Indonesia, Pustaka Pelajar, Yogyakarta, 2010, hlm. 112.

${ }^{24}$ Mukti Arto, Praktek Perkara Perdata pada Pengadilan Agama, Cet V, Pustaka Pelajar, Yogyakarta, 2004, hlm. 140.
} 
melaksanakan tugas peradilan harus benar-benar mengetahui duduk perkara yang sebenarnya, baik peraturan hukm yang tidak tertulis. ${ }^{25}$

Isi putusan pengadilan diatur dalam Pasal 50 Undang-undang Nomor 48 Tahun 2009 tentang Kekuasaan Kehakiman yang menyatakan:

1) Segala putusan pengadilan selain harus memuat alasan-alasan dan dasar-dasar putusan itu, juga harus memuat pula pasal-pasal tertentu dari peraturan-peraturan yang bersangkutan atau sumber hukum tak tertulis yang dijadikan dasar untuk mengadili.

2) Tiap putusan pengadilan ditandatangani oleh ketua serta hakim-hakim yang memutuskan dan panitera yang ikut serta bersidang. ${ }^{26}$

3. Asas-Asas Putusan

Sebagaimana dijelaskan dalam Pasal 174 HIR/Pasal 189 RBG dan beberapa Pasal 50 dalam Undang-undang Nomor 48 Tahun 2009 Tentang Kekuasaan Kehakiman, maka wajib bagi hakim sebagai aparatur negara yang diberi tugas untuk itu, untuk selalu memegang teguh asas-asas yang telah di gariskan oleh Undang-undang, agar keputusan yang di buat tidak terdapat cacat hukum yakni: memuat dasar alasan yang jelas dan rinci, wajib mengadili seluruh bagian gugatan, tidak boleh mengabulkan melebihi tuntutan, dan diucapkan di muka umum.

\section{Metode Penemuan Hukum oleh Hakim}

Penemuan Hukum merupakan hak dan tanggung jawab Hakim secara ex officio untuk mengali hukum dari sumber-sumbernya yang bersifat umum atau general sebagai das sollen baik yang beupa prinsip-prinsip (nilai-nilai) dasar sebagai hukum asal, peraturan hukum terapan yang sudahada sebagai cabang, maupun praktik hukum dalam masyarakat sebagai hukum yang hidup, dengan menggali alat hukum yang terkandung didalamnya melalui metode penemuan hukum yang tepat. ${ }^{27}$

Penemuan hukum pada umumnya merupakan kegiatan dari hakim dalam melaksanakan undang-undang bila terjadi peritiwa konkrit. Undang-undang memang harus jelas dan lengkap agar dapat berjalan efektif, namun karena banyaknya kegiatan manusia dan terbatasnya kemampuan manusia mengatur seluruh kehidupannya membuat undang-undang itu tidak lengkap dan jelas, oleh karena itu, undang-undang tidak dapat diterapkan begitu saja kedalam peristiwa konkrit. Dalam menerapkan Undang-undang tersebut harus diberi arti, dijelaskan atau ditafsirkan agar sesuai dengan peristiwanya.

${ }^{25}$ Riduan Syahrani, Hukum acara Perdata di Lingkungan Peradilan Umum, Cet. 1, Pustaka Kartini, Jakarta, 2008, hlm. 83

${ }^{26}$ Republik Indonesia, Undang-Undang Nomor 48 Tahun 2009 Tentang Kekuasaan Kehakiman, dalam Pasal 50.

${ }^{27}$ Fauzi Ardi, Penemuan Hukum Oleh Hakim Melalui Kias, Disertasi, Program Pasca Sarjana Universitas Islam Negeri Alaudin, Makassar, 2015, hlm. 54. 


\section{Kesimpulan}

Kesimpulan dari hasil penelitian di atas, sebagai berikut:

1. Pertimbangan hakim dalam penolakan pengesahan perkawinan terhadap pasangan nikah siri (Studi Perkara Nomor 0650/Pdt.P/2017/MS.Bir). Hakim mempertimbangkan bahwa kedua belah pihak istri dan suami yang mengajukan itsbat nikah ditolak karena berdasarkan fakta pada saat menikah Pemohon I berstatus terikat perkawinan dengan wanita lain dan Pemohon II berstatus terikat perkawinan dengan pria lain. Hakim berpendapat karenanya antara Pemohon I dengan pemohon II memiliki larangan perkawinan sebagaimana ketentuan Pasal 40 Kompilasi Hukum Islam yang menyatakan dilarang melangsungkan perkawinan antara seorang pria dengan seorang wanita karena keadaan tertentu, salah satunya karena wanita yang bersangkutan masih terikat satu perkawinan dengan pria lain.

2. Akibat hukum penolakan pengesahan perkawinan terhadap pasangan nikah siri (Studi Perkara Nomor 0650/Pdt.P/2017/MS.Bir). Putusan Mahkamah Syariah Bireun nomor 0650/Pdt.P/2017/MS.bir yang ditolak oleh pengadilan untuk penetapan nikah atas pertimbangan hakim. Maka dari akibat putusan tersebut yang berhubungan dengan keperdataan seperti harta gono-gini, dan menyangkut dengan status kedudukan anak tidak sahnya perkawinan.siri, artinya: seorang anak tidak diakui sebagai anak yang sah menurut Negara. Akibatnya, sianak hanya mempunyai hubungan perdata dengan ibu dan keluarga ibu dan anak tersebut juga tidak dapat menuntut nafkah dari seorang bapak.

3. Perlindungan hukum terhadap anak yang lahir dari pasangan nikah siri (Studi Perkara Nomor 0650/Pdt.P/2017/MS.Bir). Seorang Istri yang melakukan Pernikahan siri tidak memberikan perlindungan hukum kepadanya hal ini mutlak diterima kerugian bagi seorang Istri dan menguntungkan bagi suami lepas dari tanggung jawab ia sebagai seorang suami sebagaima kewajiban suami pada umumnya akan tetapi anak yang lahir dari pernikahan siri yang menyangkut dengan keperdataannya akan kembali kepada ibu.

\section{Saran}

Adapun saran yang dapat penulis berikan yaitu:

1. Diharapkan kepada Mahkamah Syar'iyah Ketika akan menolak atau menjatuhkan putusan itsbat nikah poligami, hendaknya hakim melihat mudharat yang akan timbul dikemudian hari.

2. Diharapkan kepada masyarakat Indonesia khususnya dalam wilayah Aceh untuk tidak melakukan perbuatan nikah kecuali dengan cara tercatat atau menikah di lembaga resmi KUA. Jika ingin menikah hendaklah dikaji lebih dalam terlebih dahulu stastus perkawinan calon isteri atau suomi apakah masih ada keterikatan dengan pihak lain, jika pengakuannya sudah tidak ada lagi maka dapat ditunjukkan bukti yang kuat misalnya, akta cerai, surat keterangan cerai. 
3. Diharapkan kepada masyarakat jangan melakukan pernikahan siri karena mudharatnya sangat besar bagi para pelakunya. Serta tidak punya kekuatan hukum atau payung hukum untuk melindunginya maupun anak yang dilahirkan.

\section{DAFTAR PUSTAKA}

M.Yusuf, My, Dampak Perceraian Orang Tua Terhadap Anak, Jurnal Al-Bayan, Vol, No. 29, Januari, 2014

Endang Ali Ma'sum, Pernikahan yang Tidak Dicatatkan dan Problematiaknya, Jurnal Musawa, Vol. 12, No. 2, Juli 2013, hlm. 209-219.

Kustini, Menelusuri Makna Dibalik Fenomena Perkawinan Dibawah Umur dan Perkawinan Tidak Tercatat, Kementerian Agama RI, Jakarta

Lexy J. Moleong, Penelitian Kualitatif Remaja Rosdakarya, Remaja Rosdakarya, Bandung, 2007.

Abdul Rahman Ghozali, Fiqh Munakat, Pernada Media Group, Jakarta, 2003

Kamal Mukhtar, Asas-Asas Hukum Islam Tentang Perkawinan, Bulan Bintang, Jakarta, 1974

Abdul majid Mahmud Mathalub, Panduan Hukum Keluarga Sakinah, Intermedia, Solo, 2005

Abdul Khadir M. Hukum Perdata Indonesia, Citra Aditya Bakti, Bandung, 2000

Itsnatul Lathifah, Pencatatan Perkawinan: Melacak Akar Budaya Hukum dan Respon Masyarakat Indonesia terhadap Pencatatan Perkawinan, Jurnal Al Mazahib, Vol. 3 No. 3 Juni 2015

Andi Nadir Mudar, Fenomena Itsbat Nikah Terhadap Perkawinan Yang Dilakukan Setelah Terbitnya Undang-Undang Nomor 1 Tahun 1974 Tentang Perkawinan, Jurnal Pemikiran Islam, Vol. 4, No. 2, Desember, 2018

Fitri, Y., Jamaluddin, J., \& Faisal, F. (2019). Analisis Yuridis Perceraian di Luar Pengadilan Menurut Undang-undang Nomor 1 Tahun 1974 Tentang Perkawinan Dan Menurut Pendapat Ahli Fikih Islam. Suloh: Jurnal Fakultas Hukum Universitas Malikussaleh, 7(1)

M.Anshary MK, Hukum Perkawinan di Indonesia, Pustaka Pelajar, Yogyakarta, 2010

Mukti Arto, Praktek Perkara Perdata pada Pengadilan Agama, Cet V, Pustaka Pelajar, Yogyakarta, 2004

Riduan Syahrani, Hukum acara Perdata di Lingkungan Peradilan Umum, Cet. 1, Pustaka Kartini, Jakarta, 2008

Fauzi Ardi, Penemuan Hukum Oleh Hakim Melalui Kias, Disertasi, Program Pasca Sarjana Universitas Islam Negeri Alaudin, Makassar, 2015 